\title{
Analysis of mergers and acquisitions between 2009 and 2020
}

\author{
Natalya Chernenko* / Tetiana Moiseienko / Olena Korohodova / Yaroslava Hlushchenko \\ National Technical University of Ukraine "Igor Sikorsky Kyiv Polytechnic Institute”, Department of International Economics, \\ 37 Prospect Peremohy, 03056 Kyiv 56, Ukraine
}

Received: 4 March 2021 / Accepted: 12 October 2021

\begin{abstract}
This paper studies the dynamics and trends in processes of mergers and acquisitions in a highly competitive and global economic environment. The aim of this study is to analyse and divide into periods M\&A agreements in the global economy. The study produces a precise definition and discusses benefits and drawbacks of such horizontal and vertical agreements. The authors discuss historical waves of mergers and acquisitions processes and present 11 individual periods containing special aspects and description of types of the agreements, as well as supplement the periods with COVID-19 pandemic flow for 2020-2021. A polynomial regression analysis is used to predict the mechanism, results and magnitude of mergers and acquisitions. Furthermore, a discrete time model enables studying behaviour pattern of mergers and acquisitions happened during 2009-2020. The results demonstrate that transnational companies are greatly attributed to economic growth through mergers and acquisitions despite their rather high preparation and implementation costs. It may be expected an escalation of capital redistribution among pharmaceutical and bioengineering companies in a post-pandemic period due to increased M\&A agreements.
\end{abstract}

\section{Keywords}

Acquisitions; economic transformations; mergers; transnational corporations.

\section{Análise de fusións e adquisicións entre 2009 e 2020}

\section{Resumo}

Este artigo estuda a dinámica e as tendencias nos procesos de fusións e adquisicións nun contorno económico global e altamente competitivo. 0 obxectivo deste estudo é analizar e dividir en períodos os acordos de fusións e adquisicións na economía global. 0 traballo ofrece unha definición precisa e analiza os beneficios e os inconvenientes de tales acordos horizontais e verticais. Os autores discuten ondas históricas de procesos de fusións e adquisicións, e presentan 11 períodos individuais que conteñen aspectos especiais e a descrición de tipos de acordos, ademais de complementar estes períodos cos efectos da pandemia pola COVID-19 para os anos 2020 e 2021. Utilízase unha análise de regresión polinomial para predicir o mecanismo, os resultados e a magnitude das fusións e adquisicións. Ademais, un modelo de tempo discreto permite estudar o patrón de comportamento das fusións e adquisicións que tiveron lugar durante o período 2009-2020. Os resultados demostran que o crecemento económico das empresas transnacionais se debe en gran medida ás fusións e adquisicións a pesar dos custos tan elevados de preparación e implementación destes procesos. Pódese esperar unha escalada da redistribución de capital nas empresas farmacéuticas e de bioenxeñaría nun período posterior á pandemia debido ao aumento dos acordos de fusións e adquisicións.

\section{Palabras clave}

Adquisicións; transformacións económicas; fusións; corporacións transnacionais.

JEL Codes: F21, F23, G34.

\footnotetext{
* N. Chernenko: chernenko.natalya@lll.kpi.ua (corresponding author), T. Moiseienko: moiseienko.tetiana@lll.kpi.ua, 0. Korohodova: korohodova.olena@lll.kpi.ua; Y. Hlushchenko: hlushchenko.yaroslava@lll.kpi.ua
} 


\section{Introduction}

The world economy globalization has produced a highly competitive environment where a great number of companies believe that participation in transnational mergers and acquisitions (hereinafter referred to as "M\&A") is of the essence for economic growth and competitive win. M\&A agreements represent ownership transfer and change in company control. M\&A are fundamental methods of concentration and centralization of production and capital on international scale. These processes have been in place for more than one decade and they still appear relevant.

Research of opportunities for companies to implement M\&A agreements receives wide coverage in the modern literature. Researchers from foreign countries have studied these issues for a long period. It is worth mentioning about the latest studies by Czinkota, Ronkainen \& Moffett (1997), Walker \& Hanna (1999), Hamel \& Prahalad (1996), Matsusyta (2010), Malik, Anuar, Khan \& Khan (2014), Hernandez \& Menon (2018), Cunningham, Ederer \& Ma (2020). Countries with transformational economies referred for the first time to the above phenomena already at the end of the twentieth century, at the turn of the statist economic system characterized by the stage of initial capital accumulation. Papers of national scientists contain substantially research of the processes of forced business development. Specifically, features of mergers and acquisitions in transnational entrepreneurship structures are analysed in the papers by Pashin (2002), Marchenko (2008), Busarieva (2018), Savchenko \& Shkurenko (2019).

The purpose of this study is to determine special aspects of M\&A agreements under the influence of the processes of economic growth transformation taking place in the global business environment.

The objectives of this paper are as follows:

1. Analysis of M\&A market trends under conditions of integration relations transformation;

2. assessment of motivation of companies to extensive economic growth through M\&A and demonstration of circular model of acquisition growth in the industry;

3. development of algorithm for execution of M\&A agreements incorporating stages of implementation process of such agreements;

4. elaboration of classification of M\&A agreements by types, kinds and forms using the method of system-based analysis;

5. description of stages of M\&A process development using historical and logical method;

6. outlining of prospective directions of M\&A agreements in the context of economic growth transformation under the pandemic influence;

7. analysis of behaviour pattern of announced M\&A transactions for 2009-2020 and suggestion of a polynomial regression model in predicting the scale (level of capitalization) and the results of mergers or acquisitions.

The authors present discussion on further research significance, its limitations and general conclusion in the final sections of this paper.

\section{The acquisition growth circular model (by sectors)}

For a long period, companies around the world have used efficiently M\&A as tools for corporate restructuring. From the very start, developed countries applied predominantly this approach (Roll, 1986) and thereafter they were joined by countries at early development stage. M\&A agreements in countries with emerging economies claim exceptional attention (Yanenkova \& Zeldis, 2016; Pobochenko, 2017).

Growth can be powered by acquisitions of rival firms (horizontal expansion) and of suppliers and customers (vertical integration) (Sterman, 2002). As Pardo-García \& Sempere-Monerris (2015) have 
argued, vertical mergers entail expanding forward or backward in the chain of distribution, toward the source of raw materials or toward the ultimate consumer. At the same time, horizontal mergers are usually considered harmful for consumers and society. Pardo-García \& Sempere-Monerris (2015) and Ivaldi, Jullien, Rey, Seabright \& Tirole (2003) note that both the mere exercise of market power and the possibility of tacit collusion yield outcomes that differ from the competitive ones regarding horizontal mergers.

The larger the company is, the more capital it can raise to finance mergers and acquisitions. If acquisitions consolidate the company's dominant position, profits may rise through the exercise of monopoly power over labour, suppliers, and customers, enabling the company to buy even more of its rivals ("vertical integration" in Figure 1). If vertical integration makes it possible for the company to reduce own costs, it can gain further market share, stimulate industry demand and grow even more ("power of monopoly" in Figure 1). Acquisitions can also enlarge economies of scale and scope or permit companies to guarantee a steady flow of complementary products, a process important in the convergence of the company, television, entertainment and news industries.

The synergy, often touted as the rationale for mergers, can be elusive. Many acquisitions fail to lower unit costs, stimulate economies of scale or build monopoly power. Negative loops, arising from incompatible corporate cultures, overcentralization or loss of focus, can dilute the earnings of the combined company, ultimately leading to the divestiture of the disparate business units.

M\&A agreements do not always produce a desired synergistic effect and do not provide added value for participants in all cases. At the same time, the legal and financial negotiations process can be lengthy and not cheap. In some cases, M\&A agreements are limited to the redistribution of assets, and therefore not intended to obtain synergies and increase the value of the overall company. However, organizations decide to develop through M\&A to improve a piece of the overall industry, accomplish collaborations in their different activities and to oversee resources (Fakhrullah, Zeeshan, Tariq \& Ullah, 2020). Foreign direct investment (FDI) in M\&A agreements form is increasingly used in developed countries that already have established markets (especially, compared to greenfield projects (Greenfield investment).

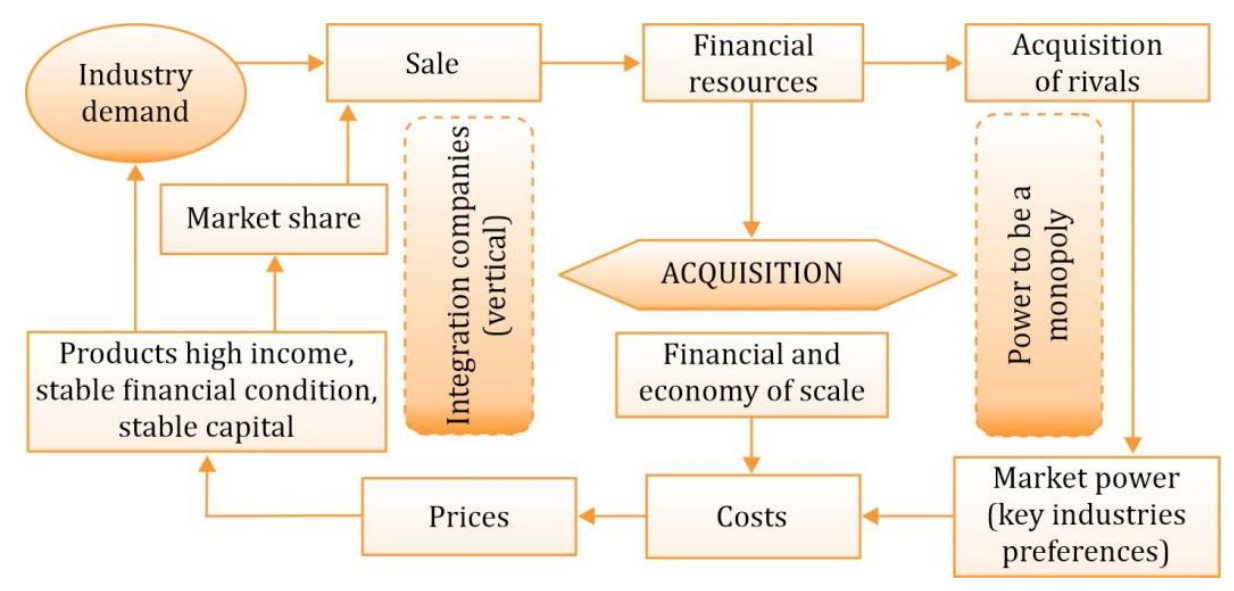

Figure 1. Circular model of acquisition growth at the industry (Sterman, 2002).

\section{Overview of M\&A historical standpoint}

Consolidation of market dominance through acquisition of weaker rivals has been a common strategy, most famously used in the late 19th and early 20th centuries by the great trusts such as US Steel, Consolidated Tobacco, Amalgamated Copper, American Smelting and Refining, Northern 
Securities and Standard Oil. In the 1920s (Sterman, 2002), 44\% of all goods in the US were made by just $1 \%$ of the industrial firms. Many of these controlled more than half the total market in their industries. The pace of merger, acquisition, and consolidation in the late 19th century has been surpassed only in the 1980s and 1990s. The rise of the trusts in the late 19th century led to a backlash in the form of the Sherman antitrust act (Sterman, 2002). In the 21st century, evaluation of potential unilateral effects in mergers is included in the US Horizontal Merger Guidelines issued in 2010 by the USDOJ and FTC (U.S. Department of Justice \& Federal Trade Commission, 2010), and included into the Guidelines on the assessment of horizontal mergers under the Council Regulation on the control of concentrations between undertakings (See European Commission, 2004), Australian Competition and Consumer Commission, Merger Guidelines, (Beaton-Wells, 2006) and others.

It remains to be seen whether the same negative feedback will arise once again in response to the growing consolidation of market power in the global economy today.

\section{Company's motivation to extensive economic growth through M\&A}

Entrepreneurial motivation for such phenomena emerges seamlessly from the logic of market behaviour of economic agents. "Performance of merger and acquisition is defined as the company's ability to create profits from merger or acquisition events carried out by the company" (Nuansari, 2020 , p. 42). This logic affords grounds for other economic activities. For example, an acquisition or complete merger with competitors makes it possible to resolve issues of competition, including the elimination of competitors through the capital and business strategies combination with them.

Following Rudenko (2008), compared to 2000 transnational M\&A, which were carried out primarily for short-term financial performance, the majority of current transnational M\&A are driven by the corporations' common strategic objectives and dictated by their existing business growth model. Empirical research of development of transnational-type entrepreneurship structures demonstrates that nowadays dominant factors, which mainstream priority of M\&A for corporations, involve the need to search and win new markets, ensure diversification of activities and product range to mitigate business risk, attain synergetic effects, personal ambitions of the top management and fear of acquisition threat by another corporation (Rudenko, 2008).

Acquisitions and real investments act as competitors both in relation to company resources (since financial resources are scarce, the increased takeover costs lead automatically to reduction in funds to be allocated to production expansion) and to their tasks within the business policy framework (for example, taking a decision on entering the country's market by takeover of a local company usually does not involve construction of a new enterprise there) and other parameters.

From the viewpoint of former owners of a captured company, the connection between the acquisition and real investment in the economy is less clear. Money received for sold business from corporations could be used efficiently for construction of a new company. To a certain degree, this situation could make up for losses suffered by the national economy as a result that companies spent their resources not on real investment, but on acquisition.

Acquisitions are considered challenging due to their complexity, high human and financial costs, as well as resources to be allocated to acquisition and integration post-merger process. Elimination of information asymmetry in the activities of the target-company seems important in development of the acquisition strategy. Information asymmetry complicates communication between corporate buyers and sellers (Capron \& Shen, 2007) and managers of private companies are particularly faced with the problem of marketing positioning to potential buyers. Therefore, while bringing a company to market, one should focus on the marketing orientation factor along with technological and economic factors, which will increase the visibility of the target-company for the potential buyer and allow M\&A agreement to be more profitable. Thus, research results (study of private biotechnology companies) (Renko, Renko \& Denooc, 2020, p. 11) demonstrate that "a venture's early market orientation and 
technology have long-term consequences for its acquisition likelihood". Renko et al (2020) determines market orientation as an acquisitions accelerator.

Transnational corporations found out a new mode of existence under conditions of the low business activity. In the area of investments, the company's growth is attributed to the great extent to acquisitions. In macroeconomic terms, this policy leads to lack of real investment. The other disadvantage of increased acquisition focus of transnational corporations (TNCs) implies accelerated variability of investment process. In practice, large investment projects involving real investment (construction of new workshops, factories, technology modernization) are known inherently for their stability. They could not be launched without a long-term preparation, i.e. construction process lasts several years, and it seems unfeasible to end up suddenly investments (at least, without incurring significant costs). On the contrary, the acquisition policy presupposes exceptional financial mobility. A large share of resources should be in a highly liquid form. This equally implies rapid investment in the process (subject to successful outcome of negotiations with the acquiring company), continuous readiness condition (in case of negotiation prolongation) and possibility of allocation to other purposes (in case of negotiation failure). It is explained by a substantial degree of uncertainty around amalgamation processes as one of the forms of TNCs business organization within a dynamic polysystem business model. The scale of transnational mergers and acquisitions confirms their importance in the TNCs activity.

\section{Algorithmization of M\&A agreements process}

Execution of M\&A agreements involves certain consecutive stages before its realization. The authors designed the algorithm of these processes as illustrated in Figure 2.

As for agreement realization (see Figure 2), Fakhrullah et al. (2020) recommends analysing all the financial statements to reveal the difference in performance and profits following one-month implementation of M\&A.

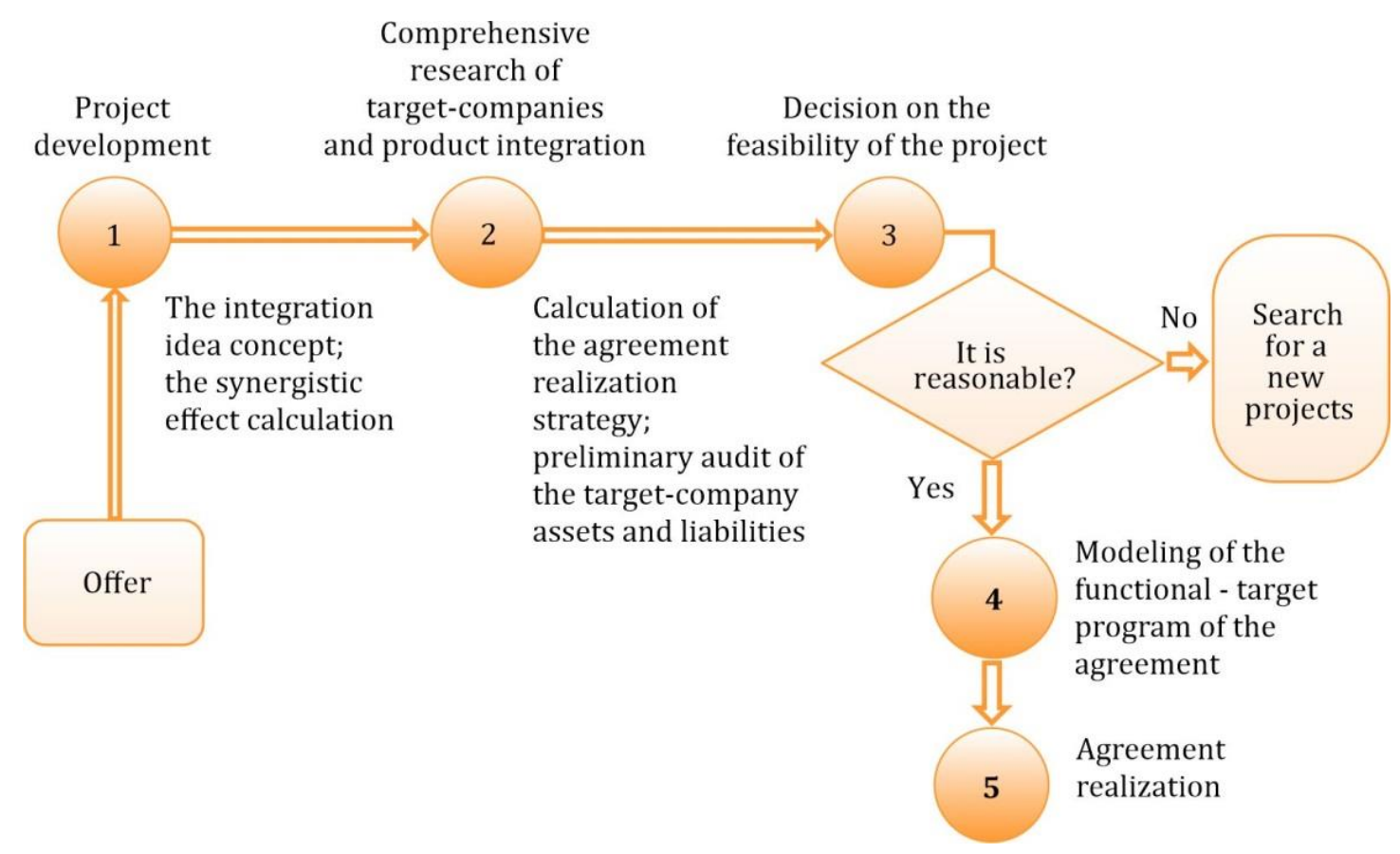

Figure 2. Algorithm of M\&A agreement process (elaborated by the authors). 
From a legal standpoint, a merger is a combination of two companies, when subsequently one of the companies remains as a legal entity. Technically, a consolidation (a "combination of charters") is not a merger. A merger requires a combination of equity participation and exchange of ordinary shares (non-taxable, called "tax-free merger"). If purchase is made in cash or through credit obligations, such merger is subject to capital gains tax. The acquiring company or its shareholders pay such tax. However, to minimize taxation, the acquiring company may depreciate the assets of the acquired company to the amount of their market value exceeding the book value. The difference is included in the total depreciation and not taxable.

Therefore, mergers can take different forms depending on various criteria. There exists a dominant approach to the merger as a combination of two or more companies through:

-Acquisition, when the amount paid, equal to the book value (plus interest), is recorded in the company account books as goodwill;

-consolidation, which leads to a new company establishment, which acquires the combined net assets of consolidated companies;

-combination of equity, accounts, formation of "a pool of interests";

-accounting method in case of consolidation or merge of companies, when the balance sheet items are simply compiled. This does not lead to additional income taxation.

However, the structure of the market changes subsequent to the merger. Specifically, the merged company produces both of the products previously produced by autonomous companies (Mills \& Weinstein, 1999). Pardo-García \& Sempere-Monerris (2015) have argued that for a vertical merger the effect from M\&A may vary depending on the type of product companies that merged into one. "Industry profits after the merger might decrease if composite goods are much differentiated since losses in different-type outsiders offset gains by the merged entity and same-type outsiders. As products become more homogeneous all profits decrease, but the merged entity is able to deal better with the increase in competition since it has more market power than companies only controlling one component".

The process of acquisition is completely different from merger, which can be defined as procurement, purchase, gain of the majority shareholding from one company to another, carried out by a raider. Raider-stock buyer is an individual or a corporation that desires to gain control over the company.

In case of acquisition, the acquiring company treats the acquired company as an investment. As a result, of the purchase, a premium is added to the real market value, which is reflected in the buyer's balance sheet as a reputation fee. If the interests are combined, the reported amount of income is higher. In case of payment for the company's reputation, the principle of accounting is preferred.

The combining interests method is used in the following events when: companies are independent for at least two years before the merger and one of them owns no more than $10 \%$ shares of the other; the merger is the result of a one-time transaction (and in case the plan is used, for a period not exceeding 1 year); payments which depend on the occurrence of certain conditions are not allowed; the buyer must issue ordinary shares of its company in the amount equivalent to or more than $90 \%$ ordinary shares of the company being purchased; the new company has no right to redeem or repurchase the shares issued during the merger or enter into an agreement in the interests of former shareholders, as well as to sell the assets of the acquired company for at least two years.

Furthermore, acquisitions often reflect the process of scientific and technical cooperation in the form of technology transfer. As Andersson \& Xiao (2016, p. 7) have argued, "acquisitions are often considered to reflect a technology transfer process and also constitute one way in which a "symbiosis" between new technology-based firms (NTBFs) and established businesses is realized". 


\section{Typology of M\&A agreements}

Scientific literature entails a certain classification of acquisition types (Hanushchak-Yefimenko \& Kobernyk, 2012; Tabakharniuk, 2017), in particular, depending on the subject - internal subject (internal shareholder or investor acquisition) and external subject (non-company investor acquisition); depending on the purpose and methods - friendly acquisition (a formal acquisition bid confirmed by the management of the absorbed company in the light of having results of synergistic effect) and aggressive or hostile acquisition (in other words, the unfriendly purchase, the company's top-management does not agree voluntarily to).

For comprehensive understanding of functional mechanism and economic effect from mergers and acquisitions, the existing approaches to M\&A agreements classification should be systematized and the typology of such agreements should be shaped (schematic), which is illustrated in Figure 3.

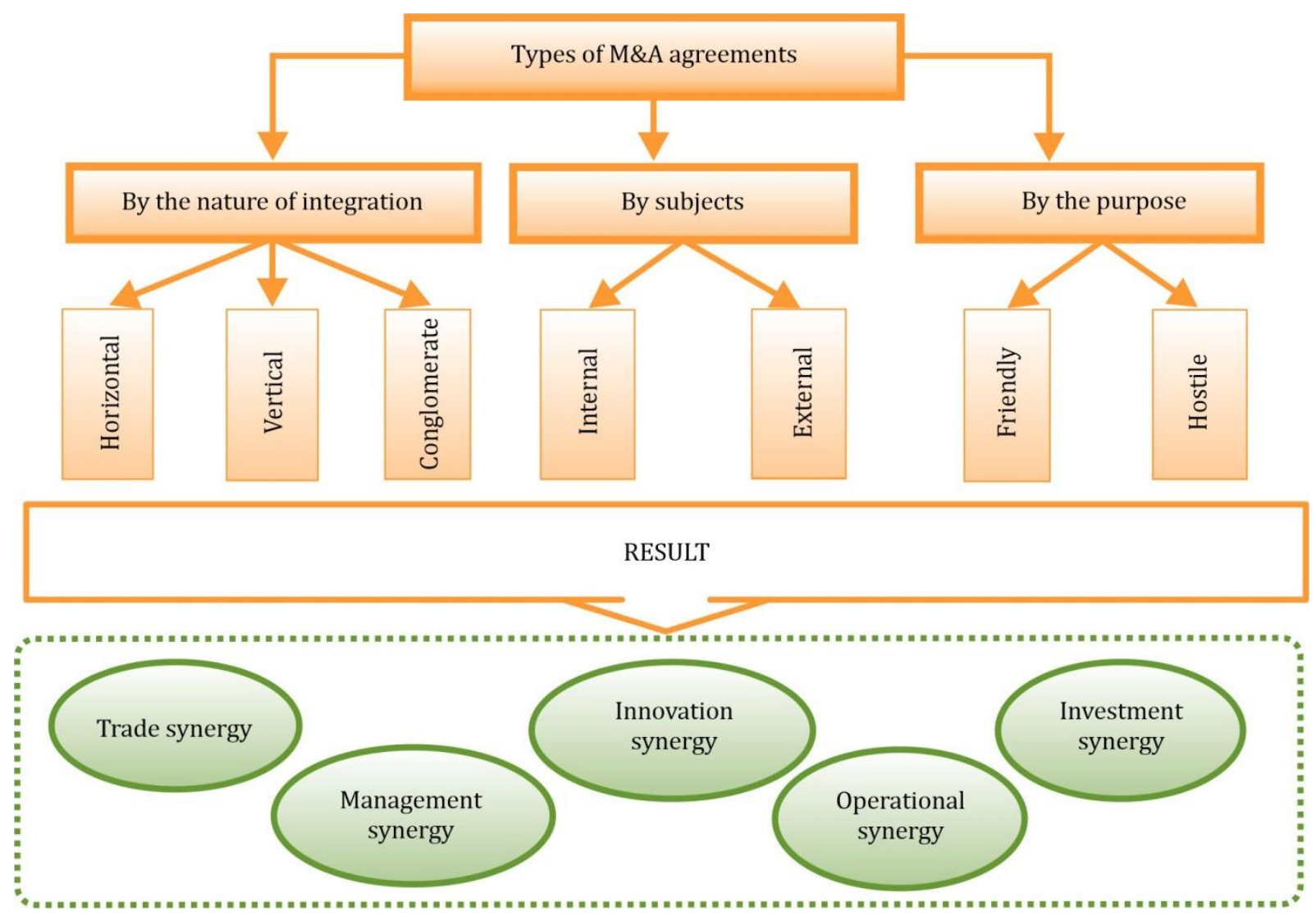

Figure 3. M\&A schematic classification with setting up a synergistic effect (created on the basis of Tabakharniuk, 2017; Hanushchak-Iefimenko \& Kobernyk, 2012; Pardo-García \& Sempere-Monerris, 2015; Devoge \& Shiraki, 2000).

In addition, it seems appropriate to classify the existing types of mergers by the nature of integrations, which is demonstrated in Figure 4.

Among the factors influencing the results of M\&A transactions, the authors distinguish external and internal ones:

The external factors include:

1) From corporations: competitors' response to M\&A; response of the companies' counterparties, participating in the agreement. 
2) From Governmental agencies: available institutional obstacles to the agreement; anti-monopoly policy; regulations of the securities market; regulation of companies' privatization process.

The internal factors incorporate:

1) The corporation's management ability to integrate transactions in a rapid manner upon the agreement conclusion.

2) The corporations' management ability to respond effectively to the response of competitors and customers to the agreement conclusion.

3) The company's expansion limits and possibility to lose control over the business.

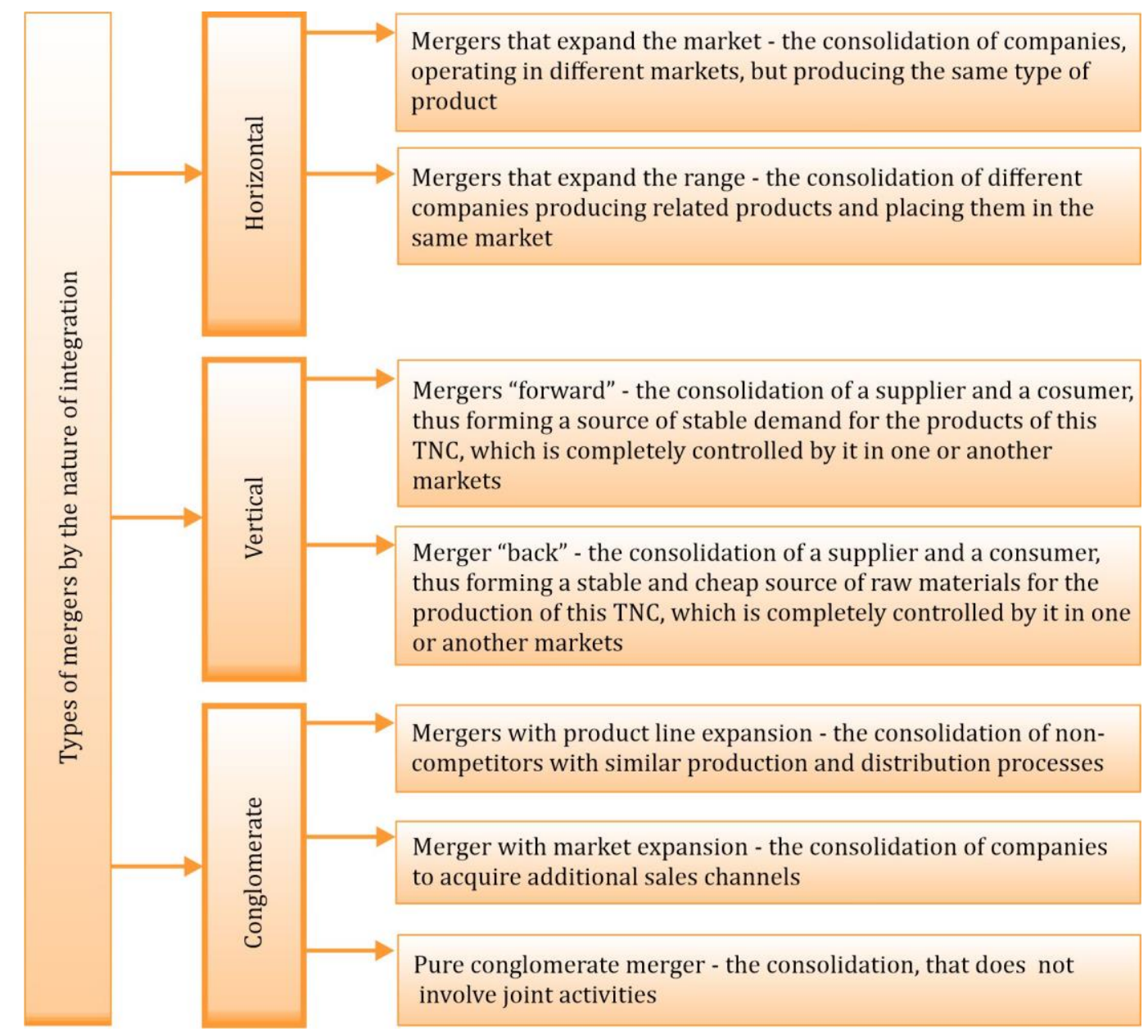

Figure 4. Classification of mergers by the nature of integration (created on the basis of Tabakharniuk, 2017; Hanushchak-Iefimenko \& Kobernyk, 2012; Pardo-García \& Sempere-Monerris, 2015; Devoge \& Shiraki, 2000).

\section{Historical waves of M\&A processes}

The historical phases of M\&A processes can be described as waves changing over the time and under the influence of various factors. The data are illustrated in Table 1.

The growing interest in M\&A agreements at the beginning of their appearance is marked by a constant increase in their quantity and value. However, with gradual and consistent stages of 
development, the situation has slightly changed. According to the Institute for Mergers, Acquisitions and Alliances (IMAA), dynamics of M\&A volume showed a decline from 2000 to 2002 (the lowest point in 2002: the number of agreements - 27,201, volume - USD 1,241.87 billion), then there was increase from 2003 to 2007 (the highest point in 2007: the number of agreements - 47,455, volume - USD 4,920.23 billion), after which there was smaller, but still rather rapid decline (the lowest point in 2009: the number of agreements - 40,710, volume - USD 2,186.91 billion). Since 2007 M\&A agreements have demonstrated essential reduction as a result of slowdown in the world economic development after 2007-2008 financial crisis (IMAA, 2020). The period 2009-2013 is characterized by slight fluctuations in growth and decline, starting from 2014 there is an increase in the share of crossborder agreements and an increase in the scale of "mega-agreements" (Busarieva, 2018). In 2014 the number of agreements totalled 47,400, the volume was USD 4,778.72 billion (IMAA, 2020).

Table 1. Historical waves of M\&A processes

\begin{tabular}{|c|c|c|}
\hline Wave & Interval, years & Characteristic \\
\hline 1 & $1897-1904$ & $\begin{array}{l}\text { By the nature of integrations - horizontal merger of companies. Business scope of activities - } \\
\text { railway transport, power industry. The principal purpose of M\&A is to gain the market monopoly } \\
\text { by the largest manufacturers. "Maximum of the deals that were started in the first period of M\&A } \\
\text { proved to be unsuccessful as the deals failed to accomplish the set goals and objectives" (Malik et } \\
\text { al., 2014). }\end{array}$ \\
\hline 2 & $1916-1929$ & $\begin{array}{l}\text { By the nature of integrations - horizontal or conglomerate merger of companies. Business scope } \\
\text { of activities - ore mining, minerals, food, chemical industry, transport industry. Increase of } \\
\text { investment banks' role in M\&A (Malik et al., 2014). The principal purpose of M\&A is creation of } \\
\text { oligopolies. }\end{array}$ \\
\hline 3 & $1965-1969$ & $\begin{array}{l}\text { By the nature of integrations - conglomerate merger of companies dominated (Malik et al., 2014). } \\
\text { Reduction of investment banks' role in M\&A, increase of the role of capital owners. }\end{array}$ \\
\hline 4 & 1981-1989 & $\begin{array}{l}\text { Increase in the share of hostile mergers (Roll, 1986). Business scope of activities - oil and gas, } \\
\text { pharmaceutical, aviation, banking industries (Malik et al., 2014). The purpose is to obtain } \\
\text { speculative income through debt redemption. "Until the revision of the Department of Justice and } \\
\text { Federal Trade Commission Horizontal Merger Guidelines in 1992, the focus had been very much } \\
\text { on coordinated effects (that is, the potential for a merger to engender collusion between the } \\
\text { merged firm and remaining rival firms)" (Beaton-Wells, 2006). }\end{array}$ \\
\hline 5 & $1992-2000$ & $\begin{array}{l}\text { Business scope of activities - banking and telecommunications industries (Malik et al., 2014). The } \\
\text { purpose is a strategic "mega-merger". Increase in the number of transnational agreements, } \\
\text { primarily for short-term financial results (Rudenko, 2008). "Driven largely by the growth in } \\
\text { differentiated products and services industries and advances in empirical techniques for } \\
\text { predicting merger outcomes, unilateral effects analysis has been the primary focus of merger } \\
\text { activity" (Beaton-Wells, 2006). }\end{array}$ \\
\hline 6 & $2000-2008$ & $\begin{array}{l}\text { Globalization as a determinant of M\&A. The Government support for mergers and acquisitions } \\
\text { (France, Italy, Ukraine). Business scope of activities - metallurgy, oil and gas, banking and health } \\
\text { care industries. Increase in the number of transactions in emerging markets. Increase in the } \\
\text { number of start-up acquisition deals. Considering the newly created companies, one should note } \\
\text { that selling the business to a functioning firm and get income through the "market of ideas" has } \\
\text { been advanced as a start-up warranted commercialization strategy (Andersson \& Xiao, 2020; } \\
\text { Gans \& Stern, 2003). }\end{array}$ \\
\hline 7 & $2008-2009$ & $\begin{array}{l}\text { High-tech industries are the growth scope for many companies, increase in the number of the } \\
\text { cross-border transactions (the Governments act as participants and regulators in the integration } \\
\text { agreements markets). "Weakened companies will need buyers to survive, while strong firms will } \\
\text { take advantage of low stock market valuations to buy troubled rivals" (Shukla \& Rizvi, 2009, p. 4). }\end{array}$ \\
\hline
\end{tabular}


Table 1 (continuation). Historical waves of M\&A processes

\begin{tabular}{|c|c|c|}
\hline Wave & Interval, years & Characteristic \\
\hline 8 & $2010-2014$ & $\begin{array}{l}\text { Strengthening the impact of reshoring processes on the TNCs activities, which is closely related to } \\
\text { the reindustrialization processes (European Commission, 2014; United Nations, 2020), nowadays } \\
\text { is again considered as a source of social prosperity and a majority factor in economic growth. }\end{array}$ \\
\hline 9 & 2014-2019 & $\begin{array}{l}\text { Industry } 4.0 \text { - enhancing the impact on the world economic development. The global investment } \\
\text { strategies of TNCs are transformed in the conditions of Industry } 4.0 \text {, included in the range of } \\
\text { interests of cyber physical systems, digital ecosystems, biotechnology, big data analytics } \\
\text { (Chernenko, Korohodova, Moiseienko \& Hlushchenko, 2020). }\end{array}$ \\
\hline 10 & 2020-2021 & $\begin{array}{l}\text { As a result of the pandemic, there is a decline in M\&A, but the pace is slower than after } 2007-2008 \\
\text { financial crisis. The most intense recession is observed in announced transactions value, more } \\
\text { than USD } \$ 1 \text { billion (IMAA, 2020). }\end{array}$ \\
\hline 11 & from 2021 & $\begin{array}{l}\text { Business scope of activities - biomedical engineering, biotechnology, pharmaceutical industry. } \\
\text { Impact of Industry } 5.0 \text { on M\&A processes }\end{array}$ \\
\hline
\end{tabular}

Source: elaborated by authors.

Starting from the year 2015 the number of agreements has reached the highest rates of 48,124 items with the volume of USD 4.3 trillion. The agreements are concluded consistently and marked by their high quality. Thus, since 2016, the number of agreements has decreased slightly, but their qualitative characteristics outweigh the quantitative ones and this trend is still relevant today.

Table 2 demonstrates the information on the world's largest agreements according to IMAA. The data indicate that the value of the world's largest agreements varied within the limit from USD 79.41 billion to USD 202.73 billion displayed a declining trend in the value of agreements.

Table 2. The largest M\&A agreements according to the IMAA (2020)

\begin{tabular}{ccccc}
\hline $\begin{array}{c}\text { Position in the } \\
\text { Institute rating }\end{array}$ & Year & Acquirer company & Target company & $\begin{array}{c}\text { Transaction value } \\
\text { (bil. USD) }\end{array}$ \\
\hline 1 & 1999 & Vodafone AirTouch PLC & Mannesmann AG & 202,7 \\
2 & 2000 & America Online Inc & Time Warner & 164,7 \\
3 & 2013 & Verizon Communications Inc & Verizon Wireless Inc & 130,2 \\
4 & 2007 & Shareholders (Spin out) & Philip Morris Intl Inc & 107,6 \\
5 & 2015 & Anheuser-Busch Inbev SA/NV & SABMiller PLC & 101,5 \\
6 & 2007 & RFS Holdings BV & ABN-AMRO Holding NV & 98,2 \\
7 & 1999 & Pfizer Inc & Warner-Lambert Co & 89,6 \\
8 & 2017 & Walt Disney Co & 21 st Century Fox Inc & 84,2 \\
9 & 2016 & AT\&T Inc & Time Warner Inc & 79,4 \\
10 & 2019 & Bristol-Myers Squibb Co & Celgene Corp & 79,4 \\
\hline
\end{tabular}

Source: elaborated by the authors and IMAA (2020).

\section{Ingluence of pandemic factors on M\&A processes. Hypothesis}

Approaches to M\&A are modified due to the impact of pandemic factors under the conditions of transformation of economic relations. 
As noted in Ernst \& Young (2020), research findings of M\&A strategy received from 2,900 top managers support these expectations:

- 73\% expect a severe impact of COVID-19 outbreak on the global economy.

$-52 \%$ take measures to change the supply chain.

$-49 \%$ indicate that they have a profit at the same level or less than 2 years ago.

$-72 \%$ are undergoing significant transformation.

$-72 \%$ conduct more frequent reviews of strategic and portfolio strategies.

$-56 \%$ actively plan to make M\&A over the next 12 months.

In 2020-2021, companies are forced to promptly and flexibly rethink, reformat and invent potential new opportunities for the functioning and development of business. These actions of companies are caused by the consequences of COVID-19 pandemic, which has provoked vulnerability problems and unforeseen challenges across all value chains.

The economic consequences, in terms of supply disruptions and behavioural changes, have become a global issue (Carrascal-Incera, Fernández Vázquez \& Serrano Gutiérrez, 2021). As Almeida (2020, p. 8) has noted,

Some sectors of the economy, such as the travel industry, entertainment, and retail were hit even harder by the shock. Affected companies were dealing with a steep and rapid decline in profits during 2020, a decline which most expected to be temporary (Almeida, 2020, p. 8).

As Hart (2020) has argued, in 2021 there will be a significant acceleration of mergers and acquisitions in the healthcare sector. A critical problem is the implication of COVID-19 for the trade policy. For example, the export restrictions and prohibitions, that various countries impose, faced a lack of medical and agricultural products, and have consequences, especially for countries without production capacity (Nunes de Faria, Grimaldo Hidalgo \& Ferraz (2021). According to Ernst \& Young (2020), companies should focus on intensifying the transformation processes, including reconfiguring capital allocation, combining portfolio content and accelerating M\&A strategy. M\&A agreements under COVID-19 remain an effective tool for rapid growth in emerging markets (Sterman, 2002).

Institute for Mergers, Acquisitions and Alliances (IMAA, 2020) notes the decline of cross-industry agreements (value more than USD 1 billion and 5 billion) in January-February 2020 to the level of 2009-2010 (Table 3).

Table 3. Dynamics of announced mergers and acquisitions for 2009-2020

\begin{tabular}{ccccc}
\hline Year & $\begin{array}{c}\text { The number of } \\
\text { transactions with } \\
\text { the value above } \\
\text { USD 5 billion }\end{array}$ & $\begin{array}{c}\text { Rate of change, } \\
\text { \%, basic } \\
\text { (basis - 2009) }\end{array}$ & $\begin{array}{c}\text { The number of } \\
\text { transactions with } \\
\text { the value above } \\
\text { USD 1 billion }\end{array}$ & $\begin{array}{c}\text { Rate of change, } \\
\text { \%, basic } \\
\text { (basis - 2009) }\end{array}$ \\
\hline 2009 & 4 & & 35 & \\
2010 & 9 & 225 & 44 & 79,5 \\
2011 & 19 & 475 & 70 & 148,6 \\
2012 & 6 & 150 & 52 & 162,8 \\
2013 & 9 & 225 & 57 & 191,4 \\
2014 & 8 & 525 & 73 & 208,6 \\
2015 & 21 & 375 & 78 & 222,9 \\
2016 & 15 & 350 & 74 & 211,4 \\
2017 & 14 & 525 & 86 & 245,7 \\
2018 & 21 & 425 & 58 & 165,7 \\
2019 & 17 & 187,5 & 47 & 132,3 \\
\hline
\end{tabular}

Source: elaborated by the authors and IMAA (2020). 
According to the above data, the rate of change in the number of announced agreements in 2020, compared to 2009 , made $132.3 \%$ for the agreements with the value above USD 1 billion. For the agreements with the value above USD 5 billion the rate of change was higher and equalled 187.5\%. However, compared to previous years, it is worth mentioning about a significant decrease. In 2020, the total number of M\&A agreements made 44,926 and their value equalled USD 2,817.38 billion.

In the context of the global fight against the consequences of COVID-19 pandemic, the M\&A processes in the area of bioengineering and pharmaceuticals generate special attention. This area is a multidisciplinary field of research, development and testing entailing a variety of sciences, such as medicine, biology, chemistry, engineering, nanotechnology and computer science. According to Crawford (2020), in 2020 the greatest influence on the world economic development transformation was produced by bioengineering research in the following areas: Tissue Engineering, Transdermal Patches, smart mobile devices woven into fabric or printed in 3D printer (Wearable Devices), Robotic Surgeons and Rehabilitation, Nanorobots, Virtual Reality, Microbubbles, Prime Editing, Organ-on-aChip, Mini Bioreactors. According to Kemp et al (2020), in 10 years or more, the most relevant issues in the bioengineering and pharmaceuticals development will be bio-based production of materials, live plant dispensers of chemical signals, malicious use of advanced neurochemistry, enhancing carbon sequestration, porcine bioengineered replacement organs and the governance of cognitive enhancement.

The data in Figure 5 demonstrate that during 2000-2020 the largest volume of M\&A in this area were observed in 2013-2014 and 2018 (USD 500.96 billion, USD 490.17 billion and USD 347.99 billion respectively).

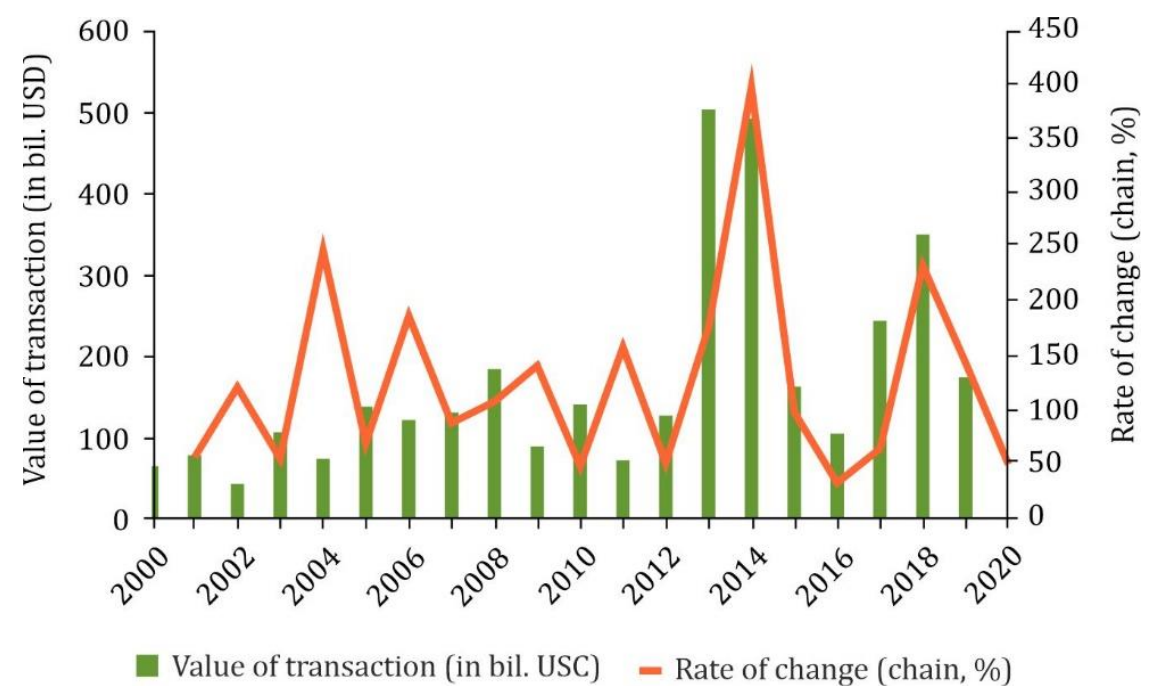

Figure 5. Dynamics of the merger operations volume in the bioengineering and pharmaceutical industries from 2000 to 2020 (IMAA, 2020)

In 2020, these processes slowed down, which can be attributed to the efforts undertaken by the companies in fighting against COVID-19. However, further development is determined by the need to address the pandemic-countering global challenge, accelerate digitalization processes and foster biomimetic and genetic engineering development (Horbatiuk, 2014; Mergers \& Acquisitions in Ukraine, 2020). However, over a short period, the issue of consolidation of capital and technological developments will become increasingly relevant.

Therefore, starting in 2021, one can expect a new wave of M\&A growth in bioengineering and pharmaceutical sectors. As Rueda-Cantuche (2021) has noted, in the conditions of COVID-19 Ireland is 
the only country in the European Union with GDP growth, mainly due to its exports of pharmaceutical products and information technology.

One of the main M\&A intensification factors in the bioengineering and pharmaceutical sectors, according to McKinsey \& Company research, is the capital of companies. The trends built on the basis of the data (Statista, 2019) on total capital raised in the biotechnology industry in the U.S. and Europe from 2015 to 2019 prove expectation of further growth in the biotechnology sector capital.

The authors used the discrete-time model as underlying for analysis of the volume of companies' capitalization in mergers and acquisitions. It helps to convert the continuous meaning of values into the discrete scale of values, which are called quantization levels. If the quantization levels are numbered, the results of these transformations will be indicated as a digit (or number) that can be expressed by any calculation system. The model, applied in the analysis, is discrete because the status of its "inputs" and "outputs" changes or measures only at discrete times.

Upon the merger or acquisition, a company puts its production plans into practical terms. Usually it undertakes activities on investment of money (financial resources, capital) into technological equipment to increase its productivity. The available capital at the merger or acquisition can be considered as innovative investments and have a stochastic return. If successful, the company may embrace the most productive technology, i.e. to increase its productivity and move towards advancing their technological boundaries, expanding them and increasing their capital. The model is in the form of a quadratic equation (parabolic or hyperbolic model) when it is necessary to determine the "cost of technological development" (the probability of capital increase is $1 / 2$ ). It assumes that the success of the merger (acquisition) is probabilistic (Equation 1). The model will be linear, if the company expects to increase capital by obtaining a new "donor" technology.

$$
K_{t}=\frac{1}{2} Z_{t}^{2} \cdot A_{t}
$$

where, $K_{t}$ is a companies' capitalization by years, in USD billion; $t$ is a time lag of the company's functioning after the merger, in years; $1 / 2$ is a probability indicator of the capital increase from technological development after the merger; $Z_{t}$ is an innovative investment of the company (recipient) which swallowed up another company (which is merged with another smaller, weaker company), in USD billion; $A_{t}$ is a production productivity; its increase can expand the technological boundaries and build up own capital (in natural or conventional measures by type of manufactured products).

Summarizing the above, it should be noted that both models, linear and parabolic (or hyperbolic), are the cases of a more sophisticated model, which is called polynomial. Based on the data (Deloitte, 2019), the authors developed a regression model of market capitalization of pharmaceutical and biotechnology companies (where $R$ is the coefficient of determination of 0.8709 , which demonstrates the compliance of the obtained function with the input data), indicating the parameters of the function that appears in it. The constructed equation is a second-order model, where the resulting indicator $(y)$ is the volume of market capitalization and the factor $(x)$ is the time, shown in years.

Polynomial regression, obtained in Figure 6, simulated the trend components of time series, namely, the capitalization of companies at the merger or acquisition (synergistic effect) by year (for the period of 2009-2018). The order of the obtained polynomial was evaluated by a special method, called "series criterion". The authors studied the polynomial regression model in the field of time series in order to predict the scale and results of mergers or acquisitions.

The dynamics of the trend (Figure 6), constructed on the basis of data (IMAA, 2020) on the total market cap of pharmaceutical and biotech companies in the A-share market from 2009 to 2018, demonstrates a steady capital increase from M\&A (almost 4 times as much). However, according to the developed model, in the future, market volumes are expected to fall.

Thus, mergers and acquisitions are a "natural phenomenon" of the market economy. Rotation of market owners is required to keep efficiency, prevent stagnation and obtain a synergistic effect of scale while achieving optimum production and complementarity of resources (InVenture, 2020; 
Pirozhok, 2019). According to the analytical estimates, about 15,000 M\&A agreements are concluded annually in the world. North America, Europe and Asia rank top in terms of the value and volume of M\&A agreements. Figure 7 illustrates the dynamic numbers of transactions at Eastern Europe, AsiaPacific, South East Asia region for the period 2000-2020. The dynamics of indicators is based on IMAA data (IMAA, 2020).

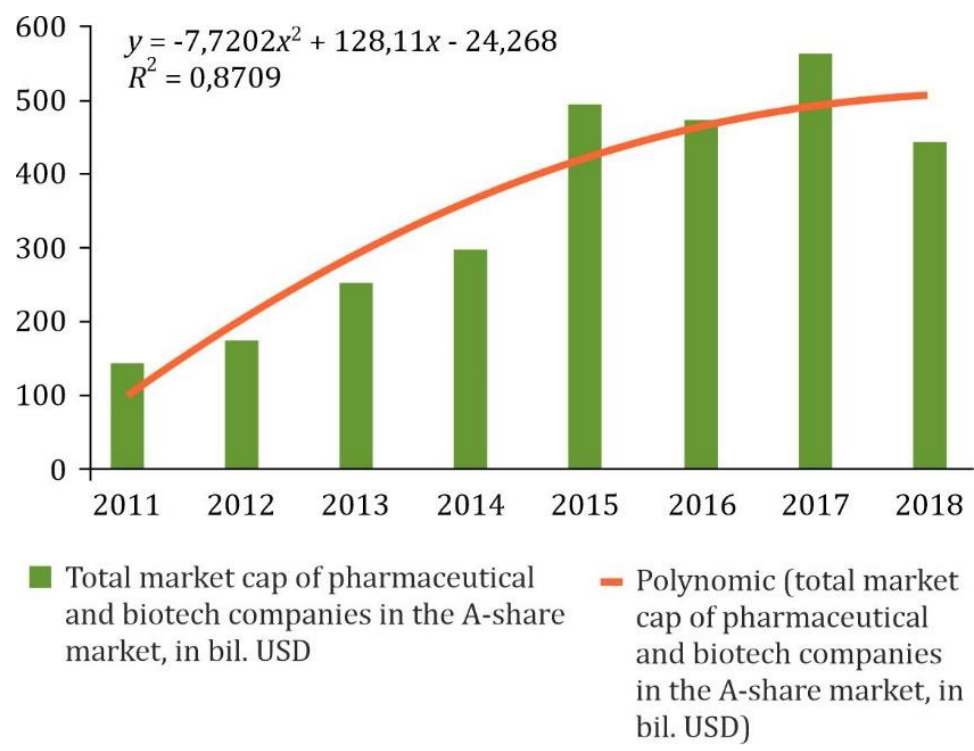

Figure 6. Dynamic of total market cap of pharmaceutical and biotech companies in the A-share market, in billion USD (Deloitte, 2019).

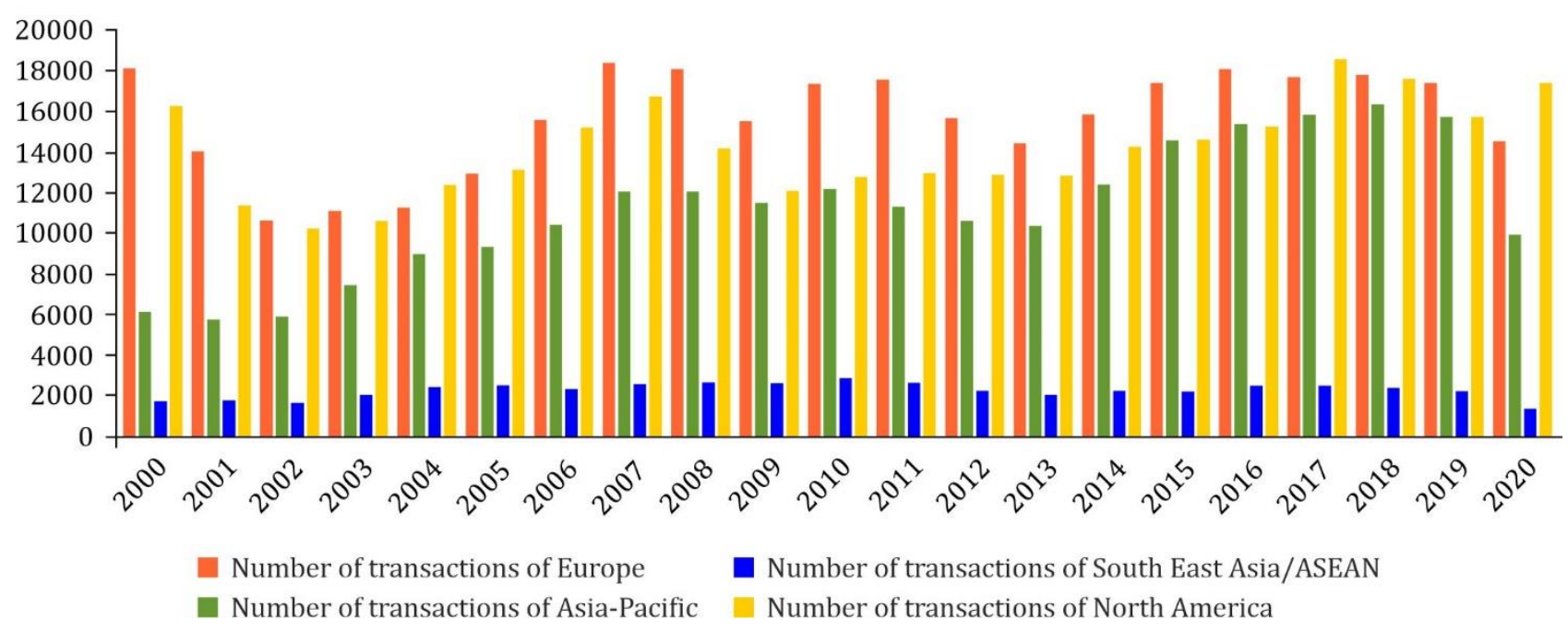

Figure 7. Dynamic numbers of transactions at Eastern Europe, Asia-Pacific, South East Asia region for the period 2000-2020 (IMAA, 2020).

According to Figure 7, the first place in terms of the value and volume of M\&A agreements is held by Asia-Pacific, they increased by 62\% for the period from 2003 to 2010 . This happened due to the establishment of oligopolistic alliances through diversification and vertical mergers of companies in 
this region. There was a relative slowdown of this process from 2011 to 2013 owing to the change in nature of M\&A agreements. Specifically "hostile" acquisitions occurred with a clearly defined strategic calculation focused on obtaining a synergetic effect from the new business alliance. The growth of M\&A agreements resumed in 2014 and totalled 26\% for the period from 2014 to 2019. COVID-19 pandemic led to a decline at the M\&A market. However, activity continued in certain areas: when some players closed their agreements planned before the quarantine, the others invested in the postcoronavirus future. Hence, M\&A entered a new phase of development, featured by the merger of transnational corporations, i.e. increase of the concentration of business alliances in global terms. Against the pandemic background, such business groups in the area of bioengineering and pharmaceuticals will help overcome the global public health problems.

\section{Conclusions}

The study concludes that the procedure of M\&A agreements implementation is treated as an efficient technique of maintaining competitive position in the context of globalization of world economic relations.

The synthesis of complementary, process and system approaches allowed the authors to develop an algorithm for executing M\&A agreements and a schematic typology of agreements with the separation of the synergetic effect components (trade, investment, innovation, management and operating).

With the use of the historical and logical method and the method of trend extrapolation, the authors could single out and supplement the history of M\&A by waves of slowing down of the analysed processes during the global outbreak and fighting against COVID-19 pandemic, as well as business alliances concentration in biomedical engineering, biotechnology, pharmaceutical industry on the Industry 5.0 basis.

Scientific novelty implies the authors' analysis of M\&A characteristics from the standpoint of the discrete-time model. This model makes it possible to survey capitalization volumes of companies taking into consideration such factors as the volume of innovative investments of a recipient-company and productivity (aggregate, both donor company and recipient company at their merger). The extrapolation trend of market capitalization of pharmaceutical and biotechnology companies (with a determination coefficient of 0.8396) supports the authors' opinion on the prospects of M\&A agreements under the conditions of economic growth transformation influenced by pandemic factors.

Data analysis of time series of M\&A transactions, subject to the value (from 2009 to 2020), evidenced the slowdown in the process of concluding agreements with the value above USD 5 billion compared to 2009 level and with the value above USD 1 billion compared to 2010 level. Geography of agreement conclusion (from 2000 to 2020) enables forecasting the leadership for North America, Europe and Asia-Pacific and continuing the trend of "hostile" acquisition.

It should be noted that increase in the level of capital concentration in the form of business alliances worldwide, especially as a hostile type of absorption, is the matter of current interest to be further studied by the authors.

Taking as a whole, the authors are to continue their study of the factors of company capitalization model and evaluation of their power of influence.

\section{Author's contribution}

Conceptualization, O.K. and T.M.; methodology, Y.H. and N.C.; validation, O.K. and N.C.; formal analysis, T.M. and O.K.; data curation: N.C. and T.M., desk data, Y.H. and O.K., field data: T.M.; writing, original draft preparation, Y.H. and N.C., review and editing, O.K. and N.C.; supervision, T.N. and Y.H.; translation, T.M., O.K. and C.N. All authors have read and agreed to the published version of the manuscript. 


\section{References}

Almeida, H. (2021). Liquidity management during the Covid-19 pandemic. Asia-Pacific Journal of Financial Studies, 50(1), 7-24. DOI: https://doi.org/10.1111/ajfs.12322

Andersson, M., \& Xiao, J. (2016). Acquisitions of start-ups by incumbent businesses. A market selection process of "high-quality" entrants? Research Policy, 45(1), 272-290.

DOI: https://doi.org/10.1016/j.respol.2015.10.002

Bakertilly International. (2019). Global dealmakers: Cross-border M\&A outlook 2019. London, UK: Bakertilly International. Retrieved from: https://bakertilly.ua/wp-content/uploads/2019/11/BakerTilly-GlobalDealmakers-Report FINAL LRHQ.pdf

Bakertilly International. (2020). Global dealmakers: European M\&A market update 2020. London, UK: Bakertilly International. Retrieved from: https://www.mergermarket.com/assets/Baker\%20Tilly\%20Global\%20Dealmakers\%20Report_2020_Final \%20LR updated.pdf

Beaton-Wells, C. (2006). Mergers without markets? Unilateral effects analysis in the United States and its prospects in Australia. Australian Business Law Review, 34, 186-210. Retrieved from: https://papers.ssrn.com/sol3/papers.cfm?abstract id=938633

Bian, J., Chan, K., \& Shi, D. (2020). Does cross-border equity trading destabilize the stock market: Evidence from Chinese stock markets? SSRN Electronic Journal. DOI: https://doi.org/10.2139/ssrn.3562001

Busarieva, T. G. (2018). Features of mergers and acquisitions of TNC. Journal of Scientific View: Economics and Management, 2, 21-28. DOI: https://doi.org/10.32836/2521-666X/2018-2-60-3

Capron L., \& Shen, J.-C. (2007). Acquisitions of private vs. public firms: private information, target selection, and acquirer returns. Strategic Management Journal, 28(9), 891-911. DOI: https://doi.org/10.1002/smj.612

Carrascal-Incera, A., Fernández Vázquez, E., \& Serrano Gutiérrez, M. (2021). COVID-19 and its economic effects: Supply chain disruptions and behavioural changes. Revista Galega de Economía, 30(1), 1-4. Retrieved from: https://revistas.usc.gal/index.php/rge/article/view/7717

Chernenko, N., Korohodova, O., Moiseienko, T., \& Hlushchenko, Y. (2020). Influence of industry 4.0 on the investment activities of transnational corporations. Scientific Horizons, 23(10), 68-77. DOI: https://doi.org/10.48077/scihor.23(10).2020.68-77

Crawford, M. (2020). Top 10 bioengineering trends for 2020. New York, NY: The American Society of Mechanical Engineers (ASME).

Retrieved from: https://www.asme.org/topics-resources/content/top-10-bioengineering-trends

Cunningham, C., Ederer, F., \& Ma, S. (2020) Killer acquisitions. Journal of Political Economy, 129(3), 649-702. DOI: https://doi.org/10.2139/ssrn.3241707

Czinkota, M., Ronkainen, I., \& Moffett, M. (1997). International business. Orlando, FL: The Dryden Press.

Deloitte. (2019). Capital market review and outlook. China: Deloitte. Retrieved from: https://www2.deloitte.com/content/dam/Deloitte/cn/Documents/finance/deloitte-cn-mna-medicine-andbiotechnology-industry-driven-by-innovative-drugs-en-190514.pdf

Devoge, S., \& Shiraki, J. (2000). People factors: The missing link in merger success. Compensation \& Benefits Management, 16(1), 26-32.

Ernst \& Young. (2020). Strategy and M\&A survey results: Global capital confidence barometer. London, UK: Ernst \& Young. Retrieved from: https://www.ey.com/en_gl/ccb

European Commission. (2004). Guidelines on the assessment of horizontal mergers under the Council Regulation on the control of concentrations between undertakings. Official Journal C 031, 5-18. Brussels, Belgium: European Commission.

Retrieved from: https://eur-lex.europa.eu/legal-content/EN/ALL/?uri=CELEX\%3A52004XC0205\%2802\%29

European Commission. (2014). Member States need to act to boost European industry. Brussels, Belgium: European Commission.

Retrieved from: https://ec.europa.eu/commission/presscorner/detail/en/MEMO 14 37

Fakhrullah, X., Zeeshan, M., Tariq, M., \& Ullah, A. (2020). How to enhance the performance of acquisitions to examine the role of dedicated mergers and acquisitions events, capabilities, and the learning process. International Journal of Social Science, Innovation and Educational Technologies, 1(4), 491-509. Retrieved from: https://zenodo.org/record/4218549\#.YWau4H3taUk

Gans, J. S., \& Stern, S. (2003). The product market and the market for "ideas": Commercialization strategies for technology entrepreneurs. Research Policy, 32(2), 333-350.

DOI: https://doi.org/10.1016/S0048-7333(02)00103-8 
Hamel, G., \& Prahalad, C. K. (1996). Competing for the future. Brighton, MI: Harvard Business School Press.

Hanushchak-Yefimenko, L. M., \& Kobernyk, I. V. (2012). The features of the formation of integrated business structures. Actual Problems of the Economy, 3(129), 154-160.

Hart, S. (2021) Three predictions for mergers and acquisitions for 2021. Jersey City, NJ: Forbes. Retrieved from: https://www.forbes.com/sites/forbesbusinessdevelopmentcouncil/2021/02/09/three-predictions-formergers-and-acquisitions-for-2021/?sh=3d190a346802

Hernandez, E., \& Menon, A. (2018). Acquisitions, node collapse, and network revolution. Management Science, 64(4), 1652-1671. DOI: https://doi.org/10.1287/mnsc.2016.2691

Horbatiuk, L. A. (2014). Market of mergers and acquisitions in the banking sector of Ukraine: Modern state and prospects of development. Business Information, 5, 352-357.

IMAA. (2020). Number \& value of $M \& A$ worldwide. Vienna, Austria: Institute for Mergers, Acquisitions and Alliances. Retrieved from: https://imaa-institute.org/mergers-and-acquisitions-statistics/

InVenture. (2020). Deals of mergers and acquisitions M\&A in Ukraine. Kiev, Ukraine: InVenture Investment Group. Retrieved from: https://inventure.com.ua/tools/database/m\%26a

Ivaldi M., Jullien B., Rey P., Seabright P., \& Tirole J. (2003). The economics of horizontal mergers: Unilateral and coordinated effects. Report for DG Competition, European Commission. Luxembourg, Luxembourg: Office for Official Publications of the European Communities. Retrieved from: https://judgestraining.eu/wpcontent/uploads/2017/06/report-eu the-economics-of-horizontal-mergers-chrysovalantou-vasilikimilliou.pdf

Kemp, L. et al. (2020). Point of view: Bioengineering horizon scan 2020. eLife 2020, 9, e54489. DOI: https://doi.org/10.7554/eLife.54489

Malik, M. F., Anuar, M. A., Khan, S., \& Khan, F. (2014). Mergers and acquisitions: A conceptual review. International Journal of Accounting and Financial Reporting, 4(2), 520-533.

DOI: http://dx.doi.org/10.5296/ijafr.v4i2.6623

Marchenko, V. M. (2008). Methodological essence of the concepts of mergers and acquisitions. Journal of Problems of Systemic Approach in the Economy, 3(7).

Retrieved from: http://jrnl.nau.edu.ua/index.php/EPSAE/article/view/4098

Matsushita, K. (2011). Mission of business. Moscow, Russia: Alpina.

Mergers and Acquisitions in Ukraine. (2021). M\&A Ukraine Infographics: TOP-10 deals on the M\&A market in Ukraine in 2017. Retrieved from: https://mergers.com.ua/images/infographics/10-Most-Prominent-M-ADeals-in-Ukraine-in-2017-Ua.jpg

Mills, R., \& Weinstein, R. (1999). Unilateral effects of mergers: The simulation approach. Retrieved from: http://www.micronomics.com/articles/Merger Paper.pdf

Nuansari, S. D. (2020). Performance of merger and acquisition, director experience, and moderation effects of board characteristics, bidder characteristics, and type of merger and acquisition. Manajemen Bisnis, 10(1), 41-48. DOI: https://doi.org/10.22219/imb.v10i1.10788

Nunes de Faria, R., Grimaldo Hidalgo, L. M., \& Ferraz, L. (2021). An assessment of trade policies related to COVID19. Revista Galega de Economía, 30(1), 1-17. DOI: https://doi.org/10.15304/rge.30.1.7334

Pardo-García, C., \& Sempere-Monerris, J. J. (2015). Equilibrium mergers in a composite good industry with efficiencies. SERIEs, 6, 101-127. DOI: https://doi.org/10.1007/s13209-014-0121-y

Pashin, S. T. (2002). Functioning of TNC's. Organizational and economic support. Moscow, Russia: Economy.

Pirozhok, O. (2019). The biggest business deals of the year: who bought whom in 2019. Newspaper of Economic Truth. Retrieved from: https://www.epravda.com.ua/publications/2020/01/13/655614/

Pobochenko, L. (2017). Regional distribution of world market processes M\&A. Development Strategy of Ukraine, 1, 70-78.

Private Equity Insights. (2020). Top 5 biggest M\&A deals struck during the pandemic. London, UK: Private Equity Insights. Retrieved from: https://pe-insights.com/news/2020/08/26/top-5-biggest-ma-deals-struck-duringthe-pandemic/

Renko, M., Yli-Renko, H., \& Denoo, L. (2020). Sold, not bought: Market orientation and technology as drivers of acquisitions of private biotechnology ventures. Journal of Business Venturing, 106022. DOI: https://doi.org/10.1016/j.jbusvent.2020.106022

Rodríguez-Monroy, C. (2006). Strategic planning and M\&A: Processes and decision support tools. International Conference on Organization Development and Change 1. Lyon, France. Retrieved from: https://www.researchgate.net/publication/277020674 strategic planning and ma processes and decision support tools 
Roll, R. (1986). The hubris hypothesis of corporate takeovers. Journal of Business, 59(2), part 1, $197-216$. Retrieved from: https://www.jstor.org/stable/2353017?seq=1\#metadata info tab contents

Rudenko, L. (2008). Advantages and risks of transnationalization of economic development of Ukraine. National Security: Ukrainian Dimension, 1(20-21), 58-68.

Rueda-Cantuche, J. M. (2021). The economy of the European Union in times of COVID-19. Revista Galega de Economía, 30(1), 1-17. DOI: https://doi.org/10.15304/rge.30.1.7663

Ruiz Barbadillo, E., \& Rodríguez Castro, P. (2013). The nature of competition in the audit market. An evaluation of the literature. Revista Galega de Economía, 22(1), 281-306. DOI: https://doi.org/10.15304/rge.22.1.1282

Savchenko, M. V., \& Shkurenko, O. V. (2019). Mergers and acquisitions as a tool for increasing the competitiveness of companies. Management of Economy: Theory and Practice, 92-105.

Shukla, B., \& Rizvi, Y. (2009). Managing organisational change: An empirical study of human resource interventions in mergers and acquisitions. The International Journal of Knowledge, Culture and Change Management, 9(7), 27-52. Retrieved from: https://www.researchgate.net/publication/343962193_Managing_Organisation_Change An_Empirical Study of Human Resource Interventions in Mergers and Acquisitions

Statista. (2019). Total capital raised in the biotechnology industry in the U.S. and Europe from 2015 to 2019. Health, Pharma \& Medtech. Retrieved from: https://www.statista.com/statistics/440971/total-capital-raisedin-biotechnology-industry-in-us-and-europe/

Sterman, J. D. (2002). System dynamics: Systems thinking and modeling for a complex world. Working Paper Series ESD-WP-2003-01.13-ESD International Symposium. Cambridge, MA: Massachussetts Institute of Technology, Engineering Systems Division. Retrieved from: https://dspace.mit.edu/bitstream/handle/1721.1/102741/esd-wp-200301.13.pdf? sequence $=1$ \&isAllowed $=y$

Tabakharniuk, M. (2017). Classification of merger and acquisition agreements in the modern economy. Scientific Bulletin of Kherson State University, 23, 110-114.

Tirole, J. (2001). Corporate governance. Econometrica, 69(1), 1-35.

Retrieved from: http://ecoapli1.udc.es/maixe-altes/banca/tema2/Tema\%20cajas/Tirole,J.\%282001\%29.pdf

United Nations. Industrial Development Organization. (2020). Industrialization as the driver of sustained prosperity. Vienna, Austria: United Nations. Industrial Development Organization. Retrieved from: https://www.unido.org/sites/default/files/files/2020-04/UNIDO_Industrialization_Book web4.pdf

United Nations. Division for Sustainable Development Goals. (2020). 17 Sustainable development goals, 17 partnerships. New York, NY: United Nations. Division for Sustainable Development Goals. Retrieved from: https://sdgs.un.org/sites/default/files/publications/211617\%20Goals\%2017\%20Partnerships.pdf

U.S. Department of Justice and the Federal Trade Commission. (2010). Horizontal merger guidelines. New York, NY: U.S. Departament of Justice and the Federal Trade Commission.

Retrieved from: http://www.justice.gov/atr/public/guidelines/hmg-2010.html

Walker, P., \& Hanna, D. (1999). What makes a merger successful? Strategic Finance, 80 (10), 58-62.

Yanenkova, I., \& Zeldis, V. (2016). M\&A features in Ukraine and Europe. Scientific papers: Ekonomy, 263, 70-76. 